\title{
Chinese academies promise cleaner elections
}

\section{Researchers call for further reforms in selection process for prestigious membership.}

\section{BY JANE QIU IN BEIJING}

$\mathrm{B}$ eing elected as an academician in China can be a passport to political influence and financial reward. Members of the Chinese Academy of Sciences (CAS) and the Chinese Academy of Engineering (CAE) are supposed to represent the cream of the country's research, and are often invited to sit on powerful government committees. In

some provinces they are offered the same official ranking as a vice-minister, and are favoured with prize money, cars, houses and personal doctors. The pursuit of these prestigious posts can involve intensive lobbying and even bribery.

This year's academy elections are already in full swing, and both societies are promising to clean up the process through transparent and rigorous oversight. They are publishing their shortlists and inviting public comment at every stage of selection, and saying that they will take allegations of misconduct more seriously than ever before. This new openness is throwing prospective academicians under increasing scrutiny.

Witness the case of Duan Zhenhao, a geologist at the CAS's Institute of Geology and Geophysics (IGG) in Beijing. He was one of 314 candidates nominated to the CAS this year; two rounds of voting will whittle that list down to a maximum of 60 . But, last month, after Duan was accused on an Internet forum of embezzling research funds, the CAS began an unusually swift investigation. Duan was detained by police. Both the CAS and the IGG declined to comment on the matter, and Duan did not respond to interview requests.

Fang Shimin, a US-trained biochemist who runs a website (www.xys.org) exposing research misconduct in China, welcomes the
CAS's quick response to the allegations, but says that investigations of alleged misconduct by nominees still lack rigour and transparency.

Others say that the academy has made visible headway. "The CAS has significantly tightened up the election process in recent years," says Mu-ming Poo, a neuroscientist at the University of California, Berkeley, and director of the CAS Institute of Neuroscience

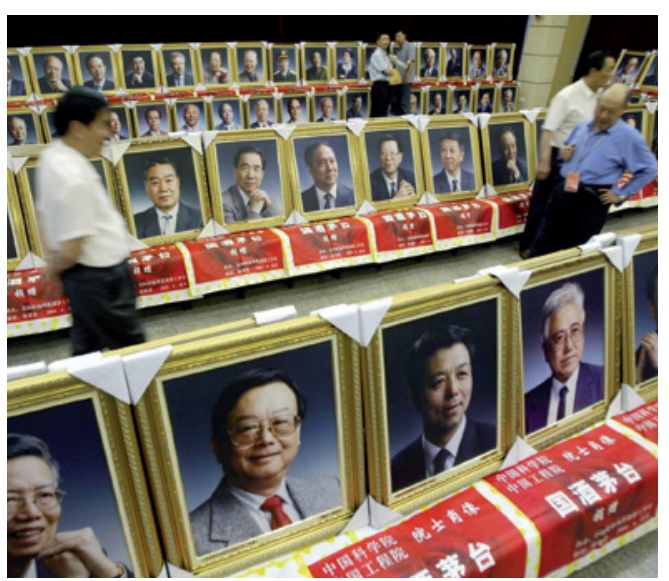

New academicians join a world of prestige and power.

in Shanghai. "I can see obvious improvement in the quality of newly elected academicians." (As a US citizen, Poo is not eligible for CAS membership.) Yao Tandong, director of the CAS Institute of Tibetan Research in Beijing, who was elected to the academy in 2007 , agrees that the evaluation procedure for CAS academicians is now "probably one of the fairest systems in science in China”.

Meanwhile, Xu Rigan, vice-president of the CAE, last month told the Xinhua news agency that his academy plans to improve its own election process to ensure that only those who have made significant contributions to engineering or clinical science become academicians. The academy has been criticized for electing a high proportion of government officials and corporate executives, and turning a blind eye to attempts to exploit the system. Nominations can come from companies and government agencies, as well as from institutions, academic associations and the academicians themselves.

These non-academic groups often run major, well-financed election campaigns, but the CAE is clamping down on such methods. In his statement to Xinhua, Xu said "those who cheat or try to use inappropriate means to get elected will lose their candidacy this year".

When the CAE announced in June that it had selected 163 candidates from a list of 485 nominees, several nominated government officials and company executives had apparently failed to make the cut — among them the deputy mayor of Shanghai and the chairman of state oil giant Sinopec. Rejected candidates had not demonstrated adequate academic contributions, says $\mathrm{Xu}$.

But Gu Haibin, an economist at the Renmin University of China in Beijing, who has studied the system for ten years, believes that the academies' efforts don't go far enough. "Promises to clean up the elections mask a deeper institutional problem," he says.

$\mathrm{Gu}$ argues that the current academician system reinforces guan ben wei, the belief that political power and status are more important than any other achievement. This means that many academics act as if the ultimate goal of their academic endeavours is political advancement, rather than producing quality research.

"The whole system is rotten to the core," says Gu. "Guan ben wei is deeply rooted in Chinese society and is poisoning all aspects of academic life." -

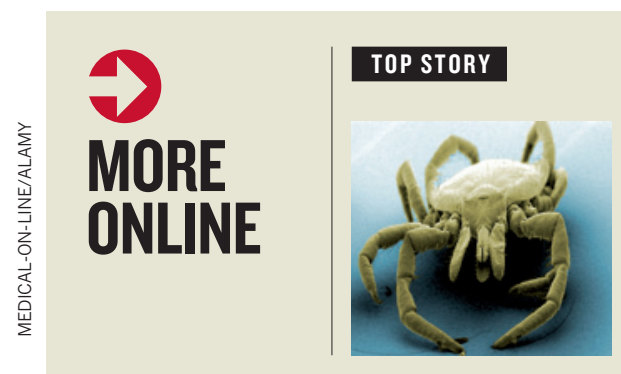

Antibodies linked to long-term Lyme disease symptoms go.nature.com/ ktif8o

\section{MORE NEWS}

- Gene-therapy enzymes make unpredicted errors go.nature.com/yegtcj - Wetlands not aided by Mississippi diversions go.nature.com/qticwp - Brazil promises 75,000 scholarships in science and technology go.nature.com/eswitrp

\section{VIDEO}

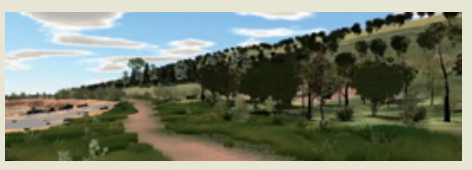

Going for a walk in the virtual countryside go.nature.com/ikedoc 